\title{
Synthesis, characterization, biological screening and determination of stability constants of $N, N^{\prime}$-Bis[1-(4-chlorophenyl)ethylidene] ethane-1,2-diamine
}

\author{
Muhammad Aslam ${ }^{1} \cdot$ Asad Gulzar $^{1} \cdot$ Rashad Mehmood $^{1}$ (D) $\cdot$ Zahra Noreen $^{2} \cdot$ Ghania Asad $^{1} \cdot$ Syed Salman Shafqat $^{1}$. \\ Muhammad Faizan ${ }^{1} \cdot$ Misbah Irshad ${ }^{1}$
}

Received: 26 September 2020 / Accepted: 21 December 2020 / Published online: 7 January 2021

(c) The Author(s) 2020 OPEN

\begin{abstract}
A Schiff base ligand, $N, N^{\prime}$-bis[1-(4-chlorophenyl)ethylidene]ethane-1,2-diamine (SBL), was synthesized by condensation of 4-chloroacetophenone with ethylenediamine in methanol in the presence of $\mathrm{H}_{2} \mathrm{SO}_{4}$ as catalyst. The structure of SBL was elucidated by spectroscopic ( ${ }^{1} \mathrm{H}-\mathrm{NMR},{ }^{13} \mathrm{C}-\mathrm{NMR}, \mathrm{IR}$ and MS) and elemental analyses, and also confirmed by XRD. The SBL was used to prepare metal complexes 1-2 with $\mathrm{Pb}^{+2}$ and $\mathrm{Cd}^{+2}$, respectively. The structures of the complexes were elucidated by IR, MS and elemental analyses. On the basis of electronic spectra and magnetic moment data, octahedral geometry was proposed for the synthesized complexes 1-2. The conductivity data showed the non-electrolytic nature of the complexes 1-2. The SBL and complexes 1-2 were subjected to measure their biological potential against Staphylococcus aureus, Bacillus subtilis and Escherichia coli bacteria. SBL showed non-significant anti-bacterial potential whereas complexes showed moderate potential as compared to standard impinium. In the toxicity with brine shrimp larvae, complexes showed more toxic effect than the SBL. In the experiments to determine the stability constants of SBL with $\mathrm{CuCl}_{2}, \mathrm{Cu}(\mathrm{OAC})_{2}, \mathrm{CoCl}_{2}$ and $\mathrm{Co}\left(\mathrm{NO}_{3}\right)_{2} ;$ SBL showed highest stability constants with $\mathrm{Cu}(\mathrm{OAC})_{2}$ which is $1.550 \times 10^{7}$ at 1:1 (L:M) and second highest with $\mathrm{Co}\left(\mathrm{NO}_{3}\right)_{2}$ which is $6.861 \times 10^{6}$ at 3:2 (L:M).
\end{abstract}

Keywords Schiff base ligands · Complexes · Synthesis and structure elucidation · Stability constants · Antibacterial and toxicity potentials $\cdot$ Brine shrimp assay

JEL Classification $120 \cdot 123$

Mathematical Subject Classification 92E20: Classical flows · reactions · etc. in chemistry

\section{Introduction}

Schiff bases are $\stackrel{\mathrm{C}}{\mathrm{C}}=\mathrm{N}-$ containing organic species and excellent ligands to form metal complexes [1]. They can be efficiently synthesized by the condensation of aldehydes/ ketones with primary amines and easily employed to form metal complexes [2] which show better biological activities and low cytotoxic effects as compared to parent ligand [3]. The importance of Schiff bases can be estimated as they use in biological systems for transamination and elucidation of racemization mechanisms [4]. Along with these facts, imine bond is considered responsible for various biological activities, such as antimicrobial, anticonvulsant, anti-inflammatory, antitumor [5-8], herbicidal [9],

\footnotetext{
$\triangle$ Muhammad Aslam, maslamchemist@hotmail.com; $\bowtie$ Rashad Mehmood, rashadhej@gmail.com | ${ }^{1}$ Division of Science and Technology, Department of Chemistry, University of Education, Township, Lahore, Pakistan. ${ }^{2}$ Division of Science and Technology, Department of Botany, University of Education, Township, Lahore, Pakistan.
} 
antituberculosis, anti-HIV activities and etc. [10, 11]. Due to versatile uses of Schiff bases, they have engrossed much attention and prompted us to synthesize and characterize a Schiff base ligand, $N, N^{\prime}$-bis[1-(4-chlorophenyl)ethylidene]ethane-1,2-diamine (SBL), and its $\mathrm{Pb}$ (II) and $\mathrm{Cd}(\mathrm{II})$ metal complexes (1-2). The products were further subjected to measure their antibacterial and toxicity potential, including stability constant of SBL.

\section{Experimental work}

\subsection{Material and methods}

The chemicals used for the synthesis were purchased from $\mathrm{BDH} /$ Merck and used without any further purification. The metal salts used for the synthesis were hydrated of metal (II) acetate. Pre-coated silica gel plates G-25-UV 254 were used for conducting TLC and detection was done at 254 and $366 \mathrm{~nm}$. Mettler Toledo electric balance was used for weighing. Thermo Nicolet Avatar 320 FTIR spectrometer was used to measure IR spectra through $\mathrm{KBr}$ pellets. Specord 200 UV-VIS spectrophotometer was used for measuring UV-VIS spectra. Melting points were determined on Gallenkamp apparatus and are uncorrected. Perkin Elmer 2400 Series II elemental analyzer was used for elemental analyses and Jenway 4010 was used for measuring molar conductance at room temperature in DMSO $\left(1 \times 10^{-3} \mathrm{M}\right)$. Moreover, Guy-type magnetic balance (Hertz SG8SHJ) was employed for the measurement of the magnetic moment. JEOL SX102/DA-6000 mass spectrometer was used to measure mass spectra by using glycerol as matrix and mass is given in $m / z(\%)$. The ${ }^{1} \mathrm{H}$ - and ${ }^{13} \mathrm{C}-\mathrm{NMR}$ spectra were recorded on a Bruker AMX-400 spectrometer in DMSO- $d_{6}$. The chemical shifts ( $\delta$ ) are given in ppm, relative to tetramethylsilane as an internal standard, and the scalar coupling constants $(J)$ are reported in Hertz.

\subsection{Procedure of synthesis of Schiff base (SBL)}

4-Chloroacetophenone $(0.2 \mathrm{~mol}$ in $30 \mathrm{ml} \mathrm{MeOH})$ and ethylenediamine $(0.1 \mathrm{~mol}$ in $30 \mathrm{ml} \mathrm{MeOH})$ were refluxed together at $90{ }^{\circ} \mathrm{C}$ on water bath for $4 \mathrm{~h}$. After refluxing the reaction mixture, the solvent was evaporated on a rotary evaporator up to one third of its initial volume, then acetone was added and placed in ice bath. The off white crystals of Schiff base ligand (SBL) were obtained by placing the resulting mixture for overnight at room temperature. The product was filtered and washed with cold methanol (methanol at ambient temperature), and recrystallized with methanol. The crystals were dried by keeping at reduced pressure on anhydrous $\mathrm{CaCl}_{2}$ for $12 \mathrm{~h}$. TLC was used to check the purity (Fig. 1).

\subsection{N,N'-Bis[1-(4-chlorophenyl)ethylidene] ethane-1,2-diamine (SBL)}

Off-white crystals; yield: $75 \%$; m.p. $168^{\circ} \mathrm{C}$; Anal. Calcd. for $\mathrm{C}_{18} \mathrm{H}_{18} \mathrm{Cl}_{2} \mathrm{~N}_{2}: \mathrm{C} 64.91, \mathrm{H} 5.58, \mathrm{~N}$ 8.52. Found: C 64.87, H 5.54, $\mathrm{N} \mathrm{8.41;} \mathrm{IR} \mathrm{(KBr):} 2850(\mathrm{C}-\mathrm{H}), 1625(\mathrm{C}=\mathrm{N}), 1601-1410$ (benzene ring) $\mathrm{cm}^{-1} ;{ }^{1} \mathrm{H}-\mathrm{NMR}\left(300 \mathrm{MHz}\right.$, DMSO- $\left.d_{6}\right) \delta: 7.81(4 \mathrm{H}$, $\mathrm{d}, J=8.7 \mathrm{~Hz}, \mathrm{H}-5,-9,-14,-18), 7.43(4 \mathrm{H}, \mathrm{d}, J=8.7 \mathrm{~Hz}, \mathrm{H}-6,-8$, $-15,-17), 3.79(4 \mathrm{H}, \mathrm{s}, \mathrm{H}-10,-19), 2.22(6 \mathrm{H}, \mathrm{s}, \mathrm{H}-4,-20) ;{ }^{13} \mathrm{C}-$ NMR (400 MHz, DMSO- $\left.d_{6}, \delta / p p m\right): 163.7(C-2,-12), 139.2$ $(C-3,-13), 134.1(C-7,-16), 128.1$ (C-6, -8, -15, -17), 128.0 $(C-5,-9,-14,-18), 52.7(C-10,-19), 15.1(C-4,-20)$; FABMS $(\mathrm{m} / \mathrm{z}): 333.1[\mathrm{M}+\mathrm{H}]^{+}$.

\subsection{General procedure for the synthesis of metal complexes (1-2)}

The methanolic solution of metal salt $\left[\left(\mathrm{Pb}\left(\mathrm{CH}_{3} \mathrm{COO}\right)_{2} \cdot 3 \mathrm{H}_{2} \mathrm{O}\right.\right.$ or $\mathrm{Cd}\left(\mathrm{CH}_{3} \mathrm{COO}\right)_{2} \cdot 2 \mathrm{H}_{2} \mathrm{O}$ ] was added to a hot methanolic solution of ligand (SBL) with the molar ratio 1:2 (M:L) and refluxed for $45 \mathrm{~min}$ in boiling methanol. For complex formation, the medium was basified by drop wise adding of $1 \mathrm{~N} \mathrm{NaOH}$ in $\mathrm{MeOH}$. The complex products 1-2 (Fig. 2) were filtered off and washed with cold methanol and dried over anhydrous $\mathrm{CaCl}_{2}$ under vacuum.

\subsection{1 $\left[\mathrm{Pb}(\mathrm{BSL})_{2}(\mathrm{OAC})_{2}\right](1)$}

Pale yellow solid; yield: $61 \%$; m.p. $347{ }^{\circ} \mathrm{C}$ (decomp.); Anal. Calcd. for $\mathrm{C}_{40} \mathrm{H}_{42} \mathrm{Cl}_{4} \mathrm{~N}_{4} \mathrm{O}_{4} \mathrm{~Pb}$ : $\mathrm{C} 48.52, \mathrm{H} 4.32, \mathrm{~N}$ 5.51, $\mathrm{Pb}$ 20.81. Found: $\mathrm{C} 48.48, \mathrm{H} 4.27, \mathrm{~N}$ 5.55, $\mathrm{Pb}$ 20.89; IR $\left(\mathrm{KBr}, \mathrm{Cm}^{-1}\right): 2888(\mathrm{C}-\mathrm{H}), 1633(\mathrm{COO})_{a s^{\prime}} 1562(\mathrm{C}=\mathrm{N}), 1598$ \& 1438 (benzene ring), $1272(\mathrm{COO})_{s}, 453(\mathrm{~Pb}-\mathrm{N})$; Molar

Fig. 1 Synthesis of Schiff base ligand (SBL)

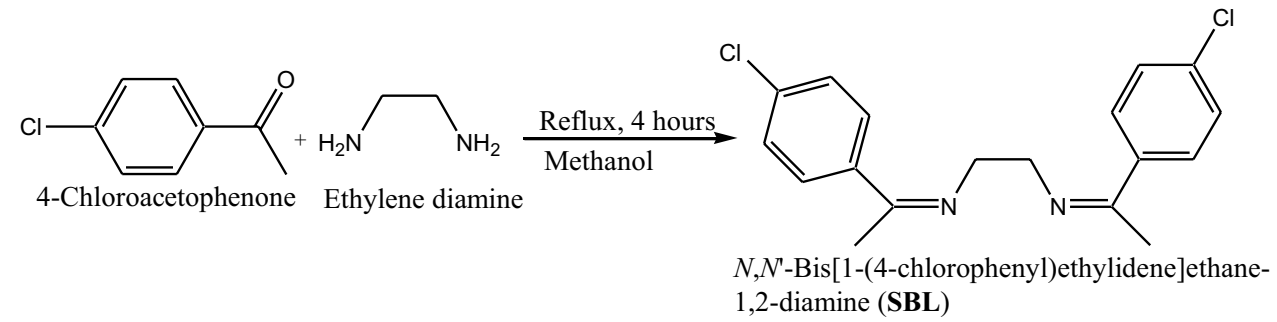

SN Applied Sciences 


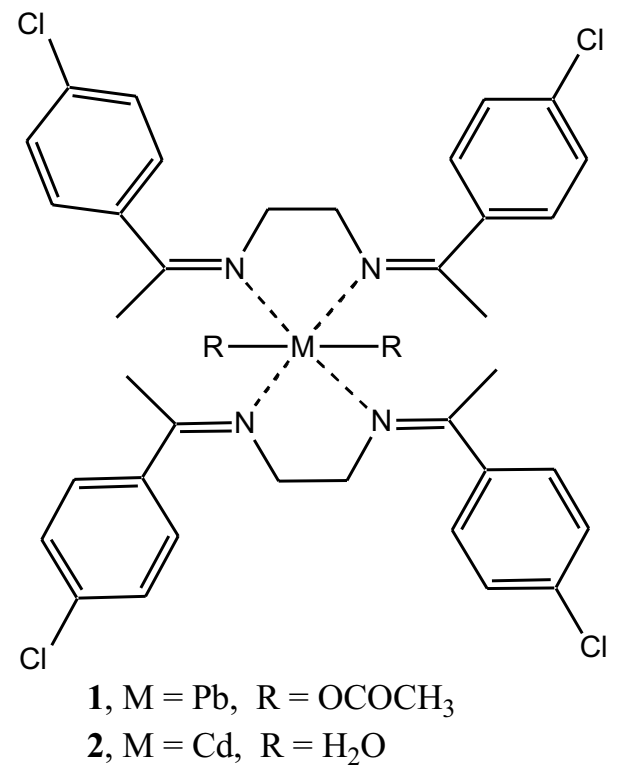

Fig. 2 Proposed structures of complexes (1-2)

conductance (DMSO) $\lambda \mathrm{m}\left(\mathrm{Ohm}^{-1} \mathrm{~cm}^{2} \mathrm{~mol}^{-1}\right): 3.1 ; \mathrm{MS}(\mathrm{m} / \mathrm{z})$ : $991.1[\mathrm{M}+\mathrm{H}]^{+}$; Magnetic moment, $\mu_{\text {eff }} \mu \mathrm{B}: 5.17$.

\subsection{2 $\left[\mathrm{Cd}(\mathrm{BSL})_{2}\left(\mathrm{H}_{2} \mathrm{O}\right)_{2}\right](2)$}

Light yellow solid; yield: $61 \%$; m.p. $210^{\circ} \mathrm{C}$ (decomp.); Anal. Calcd. for $\mathrm{C}_{36} \mathrm{H}_{40} \mathrm{Cl}_{4} \mathrm{~N}_{4} \mathrm{O}_{2} \mathrm{Cd}$ : $\mathrm{C} 53.12, \mathrm{H}$ 4.98, N 6.90, Cd 13.81. Found: C 53.06, H 4.95, N 6.87, Cd 13.79; IR (KBr) U $\left(\mathrm{cm}^{-1}\right): 3549(\mathrm{O}-\mathrm{H}), 2936(\mathrm{C}-\mathrm{H}), 1568(\mathrm{C}=\mathrm{N}), 1600$ and 1480 (benzene ring), $491(\mathrm{Cd}-\mathrm{N})$; Molar conductance (DMSO) $\lambda_{\mathrm{m}}$ $\left(\mathrm{Ohm}^{-1} \mathrm{~cm}^{2} \mathrm{~mol}^{-1}\right): 4.3$; FABMS (m/z): $815.0\left[\mathrm{M}+\mathrm{H}^{+}\right.$; Magnetic moment, $\mu_{\text {eff, }} \mu \mathrm{B}: 5.40$.

\subsection{Biological assays}

\subsubsection{Antibacterial assay}

The antibacterial potential of SBL and its complexes 1-2 was measured against Staphylococcus aureus, Escherichia coli and Bacillus subtilis bacteria. The petri plates were sterilized and $10 \mathrm{~mL}$ of nutrient medium (i.e. agar) was poured into the petri dishes and allowed it to solidify. Spore suspensions of bacteria were used for inoculation of plates. Sterilized cork borer were used for making wells in the center of plates. The solutions $(0.5 \mathrm{~mL})$ of under estimated compounds were poured into already prepared wells. The plates were inoculated at $37^{\circ} \mathrm{C}$ and after $24 \mathrm{~h}$, zone of inhibition produced in each plate around the respective wells was measured. The standard used for this purpose was impinium.

\subsubsection{Brine shrimp assay}

The artificial sea water was prepared by dissolving $3.8 \mathrm{~g}$ sea salt in double distilled and filtered water. The shrimp eggs (i.e. $1 \mathrm{mg}$ Artermia salina) were added to the small tank of sea water. The partitions of tank, having these eggs, were covered and darken with aluminium foil. The illumination of perforation in the dam was employed to attract the shrimp larvaes. The hatching and maturity of shrimps were carried out by allowing it to stand for $24 \mathrm{~h}$ at $25^{\circ} \mathrm{C}$. After two days, the mature shrimp larvae were ready. The test compounds were dissolved in DMSO to prepare samples of different concentrations $(50,100$ and $150 \mathrm{mg} / \mathrm{mL}$ ). As a result, 18 vials were prepared by making triplicate of each sample. 12 shrimps and $5 \mathrm{~mL}$ of sea water was added in each sample vial and then allowed to stay for $24 \mathrm{~h}$ under illumination. The data for shrimp lethality was analyzed by employing Finney computer programme and $\mathrm{LD}_{50}$ values were determined by counting the number of surviving shrimps $[12,13]$.

\subsection{Determination of stability constants}

Stock solutions $\left(1 \times 10^{-3} \mathrm{M}\right)$ of $\mathrm{Cu}(\mathrm{II}), \mathrm{Co}(\mathrm{II})$ and $\mathrm{SBL}$ were prepared in methanol. Stock solutions of ligand and metal were mixed in different proportions. Each proportion contained total volume as $10 \mathrm{~mL}$. Stability constants were determined at $\lambda_{\max }$ of the ligands. Stability constants of $N, N^{\prime}$-bis[1-(4-chlorophenyl)ethylidene]ethane-1,2-diamine with $\mathrm{Cu}$ (II) and $\mathrm{Co}$ (II) were determined by Job's method of continuous variation by using visible spectrophotometer. The formula to determine stability constants is shown below:

$k_{s}=\frac{(A / \text { Aex }) C^{\prime}}{\left[\left(C m-\left(\frac{A}{\text { Aex }}\right) C^{\prime}\right)\left(C x-\left(\frac{A}{\text { Aex }}\right) C^{\prime}\right)\right]}$

where

$A=$ absorbance peak.

Aex $=$ extraploted absorbance.

$\mathrm{Cm}=$ concentration of metal.

$\mathrm{C}^{\prime}=$ concentration of complex.

$\mathrm{CX}=$ concentration of ligand.

\section{Results and discussion}

$\mathrm{N}, \mathrm{N}^{\prime}$-Bis[1-(4-chlorophenyl)ethylidene]ethane-1,2-diamine (SBL) was synthesized in the form of crystalline solid with off-white colour which was insoluble in water and soluble in most common organic solvents except ether. The 
metal complexes 1-2 of the SBL were prepared in the form of solids and the decomposition temperatures of these complexes reflect the fact that they are literally stable compounds. However, the solubility behavior of these complexes is different from the Schiff base ligand as these are insoluble in water and most common organic solvents except DMF and DMSO.

\subsection{FAB mass spectra}

The mass spectra of SBL and complexes 1-2 were analyzed by the $F A B$ (positive). The pseudo molecular ion peak $[\mathrm{M}+\mathrm{H}]^{+}$at $m / z$ 333.1, indicated free $\mathbf{S B L}$ and confirmed the theoretical molecular weight which is 332.0. The stoichiometry of metal to ligand in the ratio 1:2 was supported by the observed molecular ion peaks in the spectra of complexes. The data of mass spectra were found in complete agreement to that of obtained via elemental analysis.

\subsection{Infrared spectra}

The binding mode of Schiff base ligand (SBL) to metal in the complexes 1-2 was studied by comparison of IR spectra of SBL and metal complexes. The disappearance of characteristic bands of carbonyl group, $\mathrm{v}(\mathrm{C}=\mathrm{O})$ for free 4-chloroacetophenone and peaks for $\mathrm{N}-\mathrm{H}$ str. $\mathrm{v}\left(-\mathrm{NH}_{2}\right)$ of free ethylenediamine suggested that the reaction is complete and no unreacted ketone or amine are left [14] Moreover, the azomethine band of SBL at $1625 \mathrm{~cm}^{-1}$ underwent a shift towards the lower frequency region at $1556-1569 \mathrm{~cm}^{-1}$ due to complexation of ligand with metal ion. This observation further indicated that the nitrogen atom of azomethine group is involved in coordination with metal atom and it can be described by the fact that empty $d$-orbitals of the metal atom accept the electron pair available on the nitrogen atom of azomethine group [15], a medium intensity band at $409-491 \mathrm{~cm}^{-1}$ assignable to $v(M-N)[16]$ in both complexes, further confirmed the complexation.

The bands in the region of $1400-1480 \mathrm{~cm}^{-1}$ and $1031-1099 \mathrm{~cm}^{-1} \mathrm{v}(\mathrm{C}=\mathrm{C})$ were assigned to stretching vibrations of the aromatic ring system. The acetate complexes (1) showed absorption bands at 1633 and $1681 \mathrm{~cm}^{-1}$ which were assigned to the $\mathrm{v}\left(\mathrm{COO}^{-}\right)_{a s}$ (i.e. asymmetric stretching vibrations of the acetate ion) and the bands observed at 1272 and $1278 \mathrm{~cm}^{-1}$ in acetate complexes were assigned

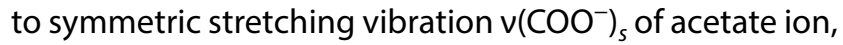
which indicated that the coordination of acetate group in a unidentate manner to central metal ion (Fig. 2).

The stretching vibration $\mathrm{v}(\mathrm{C}-\mathrm{H})$ of the methyl group of the ligand and complexes were assigned to the bands in the region of $2850-3087 \mathrm{~cm}^{-1}$. The presence of coordinated water in complex $\mathbf{2}$ was suggested by the broad band present at $3549 \mathrm{~cm}^{-1}$ (Fig. 2) $[17,18]$.

\subsection{Electronic spectra and magnetic moments}

The position, number of $d-d$ transitions and charge transfer formed the basis for stereochemistry of metal ions in complexes 1-2 and stereochemistry was assigned by observing electronic spectra. The octahedral geometry was suggested for the complexes [19] by observing electronic spectra and magnetic moment values (Table 1), which was further strengthened by the low value of molar conductance, indicating the nature of complexes as non-electrolytic.

\subsection{Molar conductance}

The molar conductivities of the complexes 1-2 were measured at ambient temperature by dissolving them in DMSO $\left(1 \times 10^{-3} \mathrm{M}\right)$. The complexes $\mathbf{1 - 2}$ were found to have molar conductance values in the range of $3.1-5.2 \Omega^{-1} \mathrm{~cm}^{2} \mathrm{~mol}^{-1}$, which indicates the non-electrolytic nature of the complexes [20].

The tentative proposed structures of the complexes 1-2 are illustrated in Fig. 2, which can be analyzed easily in the light of analytical and spectral data.

\subsection{Crystallographic studies}

Crystal data: (SBL), $\mathrm{C}_{18} \mathrm{H}_{18} \mathrm{Cl}_{2} \mathrm{~N}_{2}, \mathrm{Mr}=33.24$ g.mol ${ }^{-1}$, white rod like, $0.31,0.11,0.08 \mathrm{~mm}^{3}$, monoclinic, space group $P 2, / c, a=4.3427(2), b=10.1489(5), c=18.9213(8) \AA$, $\beta=91.458(1)^{\circ}, V=833.67(5), Z=2, D c=1.328 \mathrm{~g} . \mathrm{cm}^{-3}$, $F(000)=348$, MoKa radition, $\lambda=0.71073 \AA$, $T=296$ (2) $\mathrm{K}$, $2 \theta \max =54.0^{\circ}, 7719$ reflection collected, 2071 unique $\left(R_{\text {int }}=0.021\right)$, Final GooF $=1.083, R_{1}=0.042, w R_{2}=1.03$, $R$ indices based on 1405 reflections with $I>2 \sigma(I)$ (refinement on F2) 101 parameters, Lp and absorption correction applied, $\mu=0.39 \mathrm{~mm}^{-1}$.

Refinement: KAPPA APEX II diffractometer (Bruker) was used to collect the data under the mentioned conditioned. Cell refinement and data reduction was carried out using SAINT [21] while structure solution and refinement was done using SHELXS-97 [22]. PLATON [23] and WinGX [24]

Table 1 Electronic and magnetic moment data of complexes 1-2

\begin{tabular}{llll}
\hline Compound & $\begin{array}{l}\text { Electronic spectra } \\
\text { wavelength }\left(\mathrm{cm}^{-1}\right)\end{array}$ & $\begin{array}{l}\text { Magnetic } \\
\text { moment } \\
\text { (B.M.) }\end{array}$ & Geometry \\
\hline 1 & $9400,13,450,197,500$ & 5.17 & Octahedral \\
2 & $21,350,28,500$ & 5.40 & Octahedral \\
\hline
\end{tabular}


were used for molecular graphics. In the refinement procedure, all the non-hydrogen atoms were refined with anisotropic displacement parameters. The aromatic and aliphatic $\mathrm{C}-\mathrm{H}$ hydrogen atoms were positioned geometrically and refined as riding atom over their parent carbon atoms.

The ligand was crystalized with centro-symmetric space group to study three dimensional behavior of molecule. Crystal structure reveals that molecule gained crystallographic inversion symmetry position in unit cell. The central backbone of molecule is oriented at dihedral angle of $19.26(12)^{\circ}$ with respect to the aromatic ring (Fig. 3). Trans conformation has been observed around the two $C=N$ double bonds. The root mean square deviation values of the atoms $\mathrm{C} 7, \mathrm{C} 8, \mathrm{~N} 1$ and $\mathrm{C} 9$ from the plane generated through the $\mathrm{C} 1-\mathrm{C} 6$ are $0.072(3)^{\circ},-0.326(4)^{\circ}, 0.465(3)^{\circ}$ and $0.562(4)^{\circ}$ respectively. Molecule does not show any type of hydrogen bonding or $\pi-\pi$ interaction.

\subsection{Stability constants}

Stability constants of Schiff base ligand (SBL) with copper and cobalt were determined by Job's method of continuous variation using UV-Visible spectrophotometer at $\lambda_{\max } 320 \mathrm{~nm}$. The product was soluble in organic solvents but insoluble in distilled water. Stability constants of Schiff base ligand with copper chloride were determined as $6.336 \times 10^{4}$ at $2: 1(\mathrm{~L}: \mathrm{M})$ and $2.017 \times 10^{5}$ at $1: 1$ $(\mathrm{L}: M)$ and their log values were found as 4.802 and 5.305 , respectively. Stability constant of Schiff base with copper acetate was determined as $1.550 \times 10^{7}$ at $1: 1(\mathrm{~L}: \mathrm{M})$ and its log value was calculated as 7.190. Stability constant of Schiff base with cobalt chloride was found as $1.335 \times 10^{6}$ at 1:1 (L:M) and its log value as 6.125 . Stability constants of Schiff base with cobalt nitrate were determined as $6.861 \times 10^{6}$ at $3: 2(\mathrm{~L}: \mathrm{M})$ and $2.450 \times 10^{6}$ at $1: 4(\mathrm{~L}: \mathrm{M})$ and their log values were found as 6.836 and 6.389 , respectively. Consequently, in case of $\mathrm{Cu}^{2+}$, SBL showed highest stability constant with copper acetate at 1:1 (L:M) which is $1.550 \times 10^{7}$ whereas in case of $\mathrm{Co}^{2+}, \mathrm{SBL}$ showed highest stability constant with cobalt nitrate at 3:2 (L:M) which is $6.861 \times 10^{6}$. As a whole, the stability constant order is $1.550 \times 10^{7}$ at $1: 1(\mathrm{~L}: \mathrm{M})$ with $\mathrm{Cu}(\mathrm{OAC})_{2}>6.861 \times 10^{6}$ at $3: 2(\mathrm{~L}: \mathrm{M})$ with $\mathrm{Co}\left(\mathrm{NO}_{3}\right)_{2}>2.450 \times 10^{6}$ at $1: 4(\mathrm{~L}: \mathrm{M})$ with $\mathrm{Co}\left(\mathrm{NO}_{3}\right)_{2}>1.335 \times 10^{6}$ at 1:1 (L:M) with $\mathrm{CoCl}_{2}>2.017 \times 10^{5}$ at 1:1 (L:M) with $\mathrm{CuCl}_{2}>6.336 \times 10^{4}$ at 2:1 (L:M) with $\mathrm{CuCl}_{2}$. Stability constants determined that acetate of copper was more stable than chloride of copper whereas nitrate of cobalt was found more stable than chloride of cobalt with Schiff base (Fig. 4, Table 2).

\subsection{Biological activities}

\subsubsection{Antibacterial activity}

The agar plate technique was used to measure the antibacterial potential of Schiff base ligand (SBL) and its complexes 1-2 against $S$. aureus, E. coli and B. subtilis bacteria, and results are shown in Table 3. The studies were conducted by using $1 \%$ solution of compounds. The result showed that the SBL showed non-significant potential and less active than the metal chelates 1-2 which showed moderate potential against all strains. These facts can be explained by Tweeedy's chelation theory [25], in chelation ligand sharing its electrons with metal ion and reduces polarity of metal ion. The reduction of polarity enhances penetration of complexes into the lipid membrane and causes blockage of binding sites in the enzymes of pathogens. The phenomenon of protein synthesis is blocked by interference of complexes with the respiration processes of cell and as a result further growth of pathogens is restricted.

\subsubsection{Brine shrimp assay}

The convenient way to evaluate new bioactive synthetic products is to monitor in vivo lethality to shrimp larvae because new bioactive compounds are often cytotoxic
Fig. 3 Labelled diagram of SBL with thermal ellipsoids drawn at $50 \%$ probability

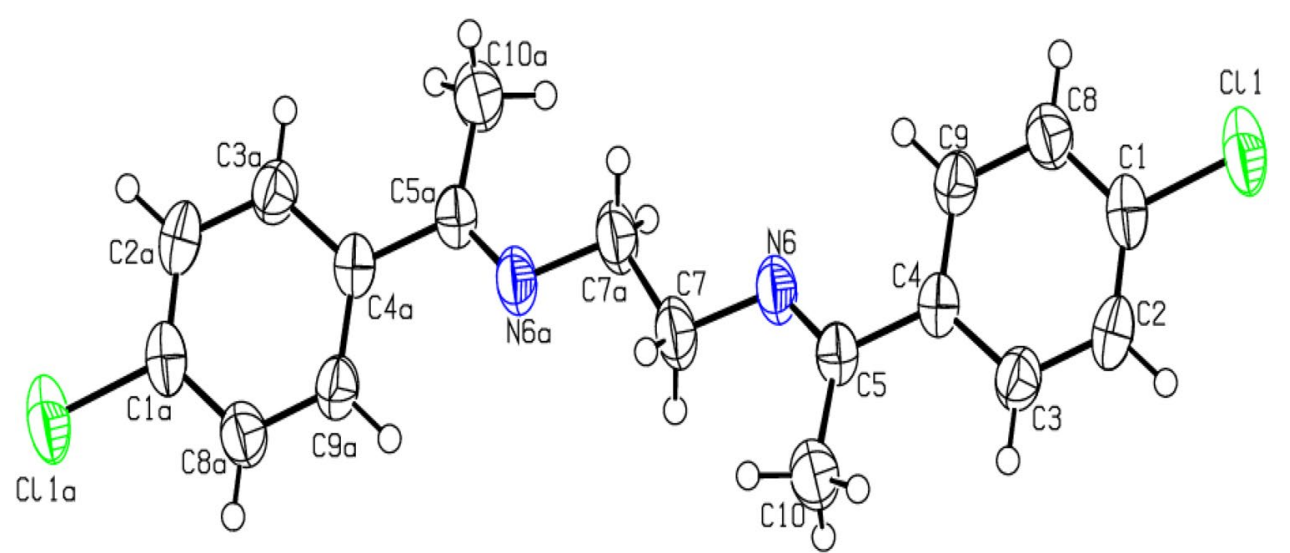

SN Applied Sciences A SPRINGER NATURE journa 

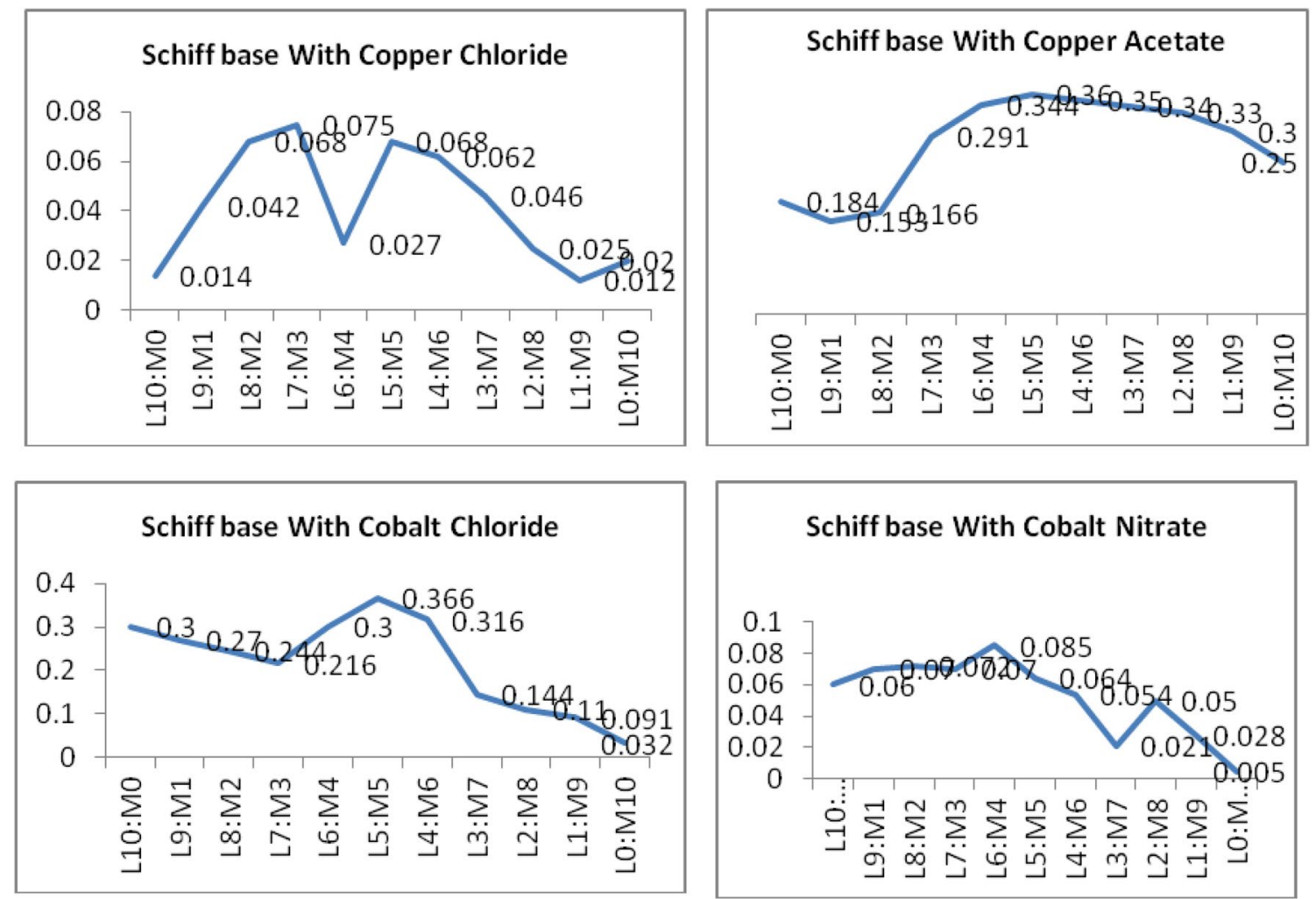

Fig. 4 Stability constants of SBL with $\mathrm{CuCl}_{2}, \mathrm{Cu}(\mathrm{OAC})_{2}, \mathrm{CoCl}_{2}$ and $\mathrm{Co}\left(\mathrm{NO}_{3}\right)_{2}$

Table 2 Stability Constants of Schiff base with $\mathrm{Cu}^{2+}$ and $\mathrm{Co}^{2+}$

\begin{tabular}{lllll}
\hline S. No & Metals & $\mathrm{L}: \mathrm{M}$ & $\mathrm{K}_{\mathrm{s}}$ & Log $\mathrm{K}$ \\
\hline 1 & $\mathrm{CuCl}_{2} \cdot 2 \mathrm{H}_{2} \mathrm{O}$ & $2: 1$ & $6.336 \times 10^{4}$ & 4.802 \\
& & $1: 1$ & $2.017 \times 10^{5}$ & 5.305 \\
& $\mathrm{Cu}\left(\mathrm{CH}_{3} \mathrm{COO}\right)_{2} \cdot \mathrm{H}_{2} \mathrm{O}$ & $1: 1$ & $1.550 \times 10^{7}$ & 7.190 \\
3 & $\mathrm{CoCl}_{2} \cdot 6 \mathrm{H}_{2} \mathrm{O}$ & $1: 1$ & $1.335 \times 10^{6}$ & 6.125 \\
4 & $\mathrm{Co}\left(\mathrm{NO}_{3}\right)_{2} \cdot 6 \mathrm{H}_{2} \mathrm{O}$ & $3: 2$ & $6.861 \times 10^{6}$ & 6.836 \\
& & $1: 4$ & $2.450 \times 10^{6}$ & 6.389 \\
\hline
\end{tabular}

Table 3 Antibacterial activity of ligand (SBL) and complexes (1-2)

\begin{tabular}{llll}
\hline Compound & \multicolumn{3}{l}{ Diameter of inhibition zone $(\mathrm{mm})$} \\
\cline { 2 - 4 } & S. aureus & E. coli & B. subtilis \\
\hline $\mathbf{L}$ & 2 & 1 & 2 \\
$\mathbf{1}$ & 4 & 4 & 6 \\
$\mathbf{2}$ & 5 & 4 & 4 \\
Impinium* & 8 & 7 & 11
\end{tabular}

*Standards

to shrimp larvae. Such type of bioassay is quick and economical in general and further in vivo animal experiments on larger scale are based on this intermediary test. Brine shrimp lethality test was used to determine the cytotoxicity of Schiff base ligand and its complexes. The considerable activity against brine shrimp nauplii was observed for the Schiff base ligand and its complexes. $\mathrm{LD}_{50}$ values of 25.52 and $45.12 \mu / \mathrm{mL}$ for complexes (1-2) show that lead complex is more cytotoxic than the other. $\mathrm{LD}_{50}$ value for the free Schiff base ligand was $61.77 \mu / \mathrm{mL}$.

\section{Conclusions}

A Schiff base, N, $N^{\prime}$-Bis[1-(4-chlorophenyl)ethylidene] ethane-1,2-diamine (SBL) and its complexes with $\mathrm{Pb}^{2+}$ and $\mathrm{Cd}^{2+}$ were synthesized in good yield and characterized by spectroscopic data. The SBL was inactive whereas metal complexes 1-2 were moderately active against selected bacteria, complexes were more cytotoxic that the parent Schiff base and complexes were of non-electrolytic nature. In the stability constant experiments, SBL showed highest stability constant with $\mathrm{Cu}(\mathrm{OAC})_{2}$ at 1:1 (L:M) ratio.

Acknowledgements Dr. Muhammad Aslam expresses his compliments to the Department of Chemistry, University of Education, Township, Lahore for providing research facilities and also to Dr. Asma Choudhry for provissssding facilities for biological activities. 


\section{Compliance with ethical standards}

Conflict of interest Authors not have any conflict of interests.

Open Access This article is licensed under a Creative Commons Attribution 4.0 International License, which permits use, sharing, adaptation, distribution and reproduction in any medium or format, as long as you give appropriate credit to the original author(s) and the source, provide a link to the Creative Commons licence, and indicate if changes were made. The images or other third party material in this article are included in the article's Creative Commons licence, unless indicated otherwise in a credit line to the material. If material is not included in the article's Creative Commons licence and your intended use is not permitted by statutory regulation or exceeds the permitted use, you will need to obtain permission directly from the copyright holder. To view a copy of this licence, visit http://creativecommons .org/licenses/by/4.0/.

\section{References}

1. Clarke B, Clarke N, Cunningham D, Higgins T, McArdle P, Cholchu MN, O'Gara M (1998) Reactions of organotin(IV) Lewis acids with $[\mathrm{M}(\mathrm{L})]_{2}$ [M-Ni, Cu and $\mathrm{Zn}$; H2L-N,N-bis(3-methoxysalicylidene) benzene-1,3-diamine and its -1,4-diamine analog]. J Organomet Chem 55:559-564

2. Ramesh R, Sivagamasundari M (2003) Synthesis, spectral and antifungal activity of Ru (II) mixed-ligand complexes. Synth React Inorg Met Org Chem 33:899-910

3. Trávníček Z, Maloň M, Šindelář Z, Doležal K, Rolčik J, Kryštof V, Strnad M, Marek J (2001) Preparation, physicochemical properties and biological activity of copper(II) complexes with 6-(2-chlorobenzylamino) purine $\left(\mathrm{HL}_{1}\right)$ or 6-(3-chlorobenzylamino)purine $\left(\mathrm{HL}_{2}\right)$. The single-crystal $\mathrm{X}$-ray structure of $\left[\mathrm{Cu}\left(\mathrm{H}+\mathrm{L}_{2}\right)_{2} \mathrm{Cl}_{3}\right] \mathrm{Cl} .2 \mathrm{H}_{2} \mathrm{O}$. J Inorg Biochem 84:23-32

4. Lau KY, Mayr A, Cheung KK (1999) Synthesis of transition metal isocyanide complexes containing hydrogen bonding sites in peripheral locations. Inorg Chim Acta 285:223-232

5. Raman N, Kulandaisamy A, Thangaraja C (2003) Redox and antimicrobial studies of transition metal (II) tetradentate Schiff base complexes. Transit Met Chem 28:29-36

6. Verma M, Pandeya SN, Singh KN, Stables JP (2004) Anticonvulsant activity of Schiff bases of isatin derivatives. Acta Pharm 54:49-56

7. Janos G, Tamas L (2009) Macrophage migration inhibitory factor (MIF) tautomerase inhibitors as potential novel antiinflammatory agents: current developments. J Curr Med Chem 16:1091-1114

8. Billman JH, Schmidgall RL (2006) Preparation and antitumor activity of some Schiff bases of 2'-Amino-4', 5'-Dichlorobenzenesulfonanilide and 2'-Amino-p-Toluenesulfonanilide. J Pharm Sci 59:1191-1194

9. Pathak P, Jolly VS, Sharma KP (2000) Synthesis and biological activities of some new substituted arylazo Schiff bases. Oriental J Chem 16:161-162
10. Mistry KM, Desai KR (2006) Microwave assisted rapid and efficient synthesis of nitrogen and sulphur containing heterocylic compounds and their pharmacological evaluation. Indian J Chem B 45:1762-1766

11. Rani BR, Bhalerao UT, Rahman MF (1990) Synthesis and biological activity of benzothiazolothiomethyl-oxadiazoles, thiadiazoles and triazoles. Indian J Chem 29:995-998

12. Finney DJ (1979) Probit analysis. Cambridge University Press, Cambridge

13. Solis PN, Wright CW, Anderson MM, Gupta MP, Phillipson JD (1993) A microwell cytotoxicity assay using Artemia salina (brine shrimp). Planta Med 59:250-252

14. Shakir M, Khanam S, Azam M, Aatif M, Firdaus F (2011) Template synthesis and spectroscopic characterization of 16-membered [N4] Schiff-base macrocyclic complexes of Co (II), Ni (II), $\mathrm{Cu}$ (II), and Zn (II): in vitro DNA-binding studies. J Coord Chem 64:3158-3168

15. Sharma VK, Srivastava S, Srivastava A (2006) Novel coordination complexes of the trivalent ruthenium, rhodium and iridium with hydrazones derived from isatin hydrazide and various aldehydes with spectral and biological characterization. Pol J Chem 80:387-396

16. Singh DP, Malik V, Kumar K, Sharma C, Aneja KR (2010) Macrocyclic metal complexes derived from 2, 6-diaminopyridine and isatin with their antibacterial and spectroscopic studies. Spectrochim Acta Part A Mol Biomol Spect 76:45-49

17. Vogel AIA (1961) A text book of quantitative inorganic chemistry. Longman, London

18. Sengupta SK, Pandey OP, Srivastava BK, Sharma VK (1998) Synthesis, structural and biochemical aspects of titanocene and zirconocene chelates of acetylferrocenyl thiosemicarbazones. Transit Met Chem 23:349-353

19. Cotton FA, Wilkinson G (1988) Advanced inorganic chemistry. Wiley, New York

20. Geary WJ (1971) The use of conductivity measurements in organic solvents for the characterisation of coordination compounds. Coord Chem Rev 7:81-22

21. Sheldrick GM (2007) SADABS Bruker Axs Inc. Madison, Wisconsin, USA

22. Sheldrick GM (2008) A short history of SHELX. Acta Cryst A 64:112-122

23. Spek AL (2009) Structure validation in chemical crystallography. Acta Cryst D Biolog Cryst 65:148-155

24. Farrugia LJ (1997) ORTEP-3 for windows-a version of ORTEP-III with a graphical user interface (GUI). J Appl Cryst 30:565-565

25. Tweedy BG (1964) Plant extracts with metal ions as potential antimicrobial agents. Phytopathology 55:910-914

Publisher's Note Springer Nature remains neutral with regard to jurisdictional claims in published maps and institutional affiliations. 